\title{
THE MULTIMEDIA CONTENT AND INTERACTIVE EDUCATIONAL ACTIVITY AS THE WAYS OF INTENSIFICATION OF THE DISTANCE LEARNING
}

\section{МУЛЬТИМЕДІЙНИЙ КОНТЕНТ ТА ІНТЕРАКТИВНА НАВЧАЛЬНА ДІЯЛЬНІСТЬ ЯК ШЛЯХИ ІНТЕНСИФІКАЦІЇ ДИСТАНЦІЙНОГО НАВЧАННЯ}

Oksana KHALABUZAR, Candidate of Pedagogical Sciences, Associate Professor

oxa-khalabuzar@ukr.net https://orcid.org/0000-0003-2338-0854

Berdiansk State Pedagogical University,

4, Schmidta St., Berdyansk, Zaporizhzhia region, 71100 Volodymyr KHALABUZAR, teacher of computer science, I category vkhalabuzar@gmail.com https://orcid.org/0000-0002-8634-0318 Berdiansk Secondary School of I-III Grades №11 Berdiansk City Council of Zaporizhia Region

9, Shevchenko av., Berdiansk, Zaporizhzhia region, 71100

Бердянська загальноосвітня школа I-III ступенів №11 Бердянської міської ради Запорізької області бул. Шевченка, 9, м. Бердянськ, Запорізька обл., 71100

Original manuscript received: December 06, 2021

Revised manuscript accepted: December 20, 2021

\begin{abstract}
Article deals with the burning problems of omplementing of the multi-media content in to the edicational process withi the distant learning. There are given notions of the distant leaning. The autores presemted some practical educational tasks which were effectively realized during the educational process. It is underlined that within modern conditions of the global pandemic processes which caused the quarantine at different levels of educational system, the distant learning became one of the most appropriate ways of teaching due to its ability not to endanger the participants of the educational process. According to the fact of the popularity of various multimedia content among the layers of primary school's pupils, secondary school's pupils we state the goal of this research work as the determination of the importance of the multimedia content as the way of the intensification of the distant learning. Along with the development of modern technologies, the distance learning has gained new wide opportunities and distinct features. Some scientists (V. Kukharenko, V. Oliynik,
\end{abstract}


V. Ribalko, P. Stefanenko) have underlined the main features of the distance learning: educational mobility, which provides the opportunity to study and to work in parallel; social equality, which provides the equal opportunities for the education regardless the place of living, the condition of the student's health, the social status of the student; interactivity which provides the active communication of the participants of the educational process; module system, which gives opportunity to create the individual or group program of education which oriented on the mastering certain knowledge and skills according to the developed educational plan; flexibility, which gives the opportunity to study during the chosen and comfortable time and place for each of the students; effectiveness of work with great amount of students; technological component which is popular with modern applicants:

Ukrainian scholars underline that the pedagogue's role was transformed and expanded because the teacher must be able to become the coordinator, organizer. This transformation makes the teacher to work creatively, to coordinate the cognitive educational process, to improve educational courses, to increase the quality of the educational content, to cooperate with the student, to join the modern society. Actually, the multimedia content can be varied from a still screenshot which was taken from a film to the whole movie or Cartoons, TV show, Weather forecasts, advertisement, announcement, slogan, Vlogs, TV program, documentary or educational film. You just have to be student-oriented and take into account their preferences during the realization of your pedagogical purpose. We suggest you to organize the discussions, surveys which could be done with the help of Google tools.

For example, during the work with the theme «English Folklore within modern reality" you are able to ask your students to watch at home some videos, films, based on English folklore. Suggest them to create and to discuss presentations which would be able to reveal and to underline the motives of English folklore which could be found in modern prose of film industry. The conducted work proved that that the implementation of distance forms of teaching provides individualization of the process of professional development of the future teacher. However we should determine the required and perfect balance of online and offline studies which would be useful and adequate for the realization of all educational goals within the modern global society. This aspect will be the prospect of our further scientific activity.

Key words: multi-media content, distant learning, educational goals.

Within modern conditions of the global pandemic processes which caused the quarantine at different levels of educational system, the distant learning became one of the most appropriate ways of teaching due to its ability not to endanger the participants of the educational process. According to the fact of the popularity of various multimedia content among the layers of primary school's pupils, secondary school's pupils we state the goal of this research work as the determination of the importance of the multimedia content as the way of the intensification of the distant learning.

Analysis of the research on the problem. According to the MerriamWebster dictionary, the distance learning is «a method of study where teachers and students do not meet in a classroom but use the Internet, e-mail, mail, etc., to have classes» [5]. The Cambridge dictionary gives the definition according to which the distant learning is «a way of studying in which you do not attend a school, college, or university, but study from where you live, usually being taught and given work to do over the internet» (https://dictionary.cambridge.org/ru/\%D1\%81\%D0\%BB\%D0\%BE\%D0\%B2\%D0 
\%B0\%D1\%80\%D1\%8C/\%D0\%B0\%D0\%BD\%D0\%B3\%D0\%BB\%D0\%B8\%D0 \%B9\%D1\%81\%D0\%BA\%D0\%B8\%D0\%B9/distance-learning)

We agree with the point of view of Michael Simonson and Gary A Berg, who stated that the distance learning could be determined as the certain form of learning, which is characterized by the physical separation of the educational process's participants. It is also characterized by the implementation of different technologies which will provide the effective communication of the teacher and student. (https://www.britannica.com/topic/distance-learning/Modern-distancelearning).

Actually the first attempts to implement the distant learning were undertaken by Y. A. Komensky with the help of his illustrated textbooks, recommendations and instruction for the home learning, which were revealed in his "Great Didactics» (https://rusneb.ru/catalog/000199000009004424522/viewer/?page=4).

During the $19^{\text {th }}$ century the "correspondence learning" appeared due to the work of the post-offices. This correspondent learning were implemented in London (1836), Chicago (1892), Queensland (1911), USSR (since 1920) etc. Within modern conditions of the independent Ukraine we can state two periods of the development of distance learning: 1995-2000 and 2000-till now. The concept of development of the distance education of Ukraine was stated in 2000. This provided the creation of the educational system which provides the extending of the circle of the applicants for the educational services; provides the realization of the constant education (during the whole life) and provides the opportunity of individualization of the education according to certain requirements of some applicants. At the second stage of development of distance learning scholars developed and improved the principles, conditions and goals of the distance learning. Thus, nowadays the distance learning in Ukraine guarantees the daytime and extramural training of the future specialists with the help of new computer technologies. Moreover, during last decade the procedures of accreditation, obtaining licenses and attestation of specialists are realized on various platforms which have been developed and adopted for the distance learning. There are some state and non-state organisations which provide the realization of new ideas concerning the distance learning: Counsil on monitoring development of distance learning, Ukrainian center of distance learning, regional centers (Kharkiv, Lviv, Odessa, etc), local centers, scientific-methodical commissions (http://www.osvita.org.ua/distance/ukraine/), etc.

Along with the development of modern technologies, the distance learning has gained new wide opportunities and distinct features. Some scientists (V. Kukharenko, V. Oliynik, V. Ribalko, P. Stefanenko) have underlined the main features of the distance learning:

- educational mobility, which provides the opportunity to study and to work in parallel; 
- social equality, which provides the equal opportunities for the education regardless the place of living, the condition of the student's health, the social status of the student;

- interactivity which provides the active communication of the participants of the educational process;

- module system, which gives opportunity to create the individual or group program of education which oriented on the mastering certain knowledge and skills according to the developed educational plan;

- flexibility, which gives the opportunity to study during the chosen and comfortable time and place for each of the students;

- effectiveness of work with great amount of students;

- technological component which is popular with modern applicants:

Ukrainian scholars underline that the pedagogue's role was transformed and expanded because the teacher must be able to become the coordinator, organizer. This transformation makes the teacher to work creatively, to coordinate the cognitive educational process, to improve educational courses, to increase the quality of the educational content, to cooperate with the student, to join the modern society.

The educational multimedia content may include different material which could be represented on various educational plafforms and other online resources. Actually there are some variants, as Skype, ooVoo, iChat, Google Meet and FaceTime or Flash Meeting. Some of this resources are free from the distracting advertising and this must be the reason for the choice.

During the distance learning we prefer to work on the platform Zoom which was founded by Eric Yuan, in April, 2011. Since that time Zoom has gained the enormous popularity due to its bright opportunities. This could explain by the fact that different software is compatible with Zoom (Android, MacOs, Windows, Linux, etc). Also as the advantages we can underline that it is free during 40 minutes of the videoconferencing which can unite up to 100 participants.

Besides, the participants are able to share the information with the help of demonstration of their screens; to communicate within the chat; to show their reactions. Within learning of the foreign languages and foreign literature the videoconferencing proved its effectiveness and productivity. Thus, during the planning of the lesson on English folklore we can suggest you to share with the students with the educational material, to add some multimedia content which will stimulate their positive motivation. For example, working with the material, we suggest to send some Qrcodes with the additional information and ask your students to watch the material, to make some tasks and to prepare their reports for the discussion.

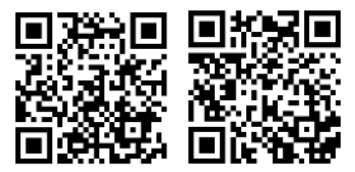


We think that it is really useful to combine watching small videos with the traditional education because it involves the change of the educational activities; adds positive emotions; adds the communicative situations, realized by the native speakers. In general, videos help us to master various language skills and gives opportunity to realize different non-standard methods of teaching. For example, before the watching of the video you can create the list of new words and ask your students to match them with their definitions. Also you can suggest them to describe certain images, personalities or phenomena from the multimedia content. For example, when you work with «Beowulf», give students as the home task to watch some links:

https://www.youtube.com/watch?v=R9K8gyfvmTg

https://www.youtube.com/watch?v=4 FTk3lOjBE

https://www.youtube.com/watch?v=DaShOr5AeKA\&list=PLTLNwZ6B Jw3E4-KIQpvUavf--snQn4Qxx.

Later, during the videoconferencing with the help of Zoom ask them to tell their opinion concerning:

- the personality of Hrothgar;

- the personality of Beowulf;

- the personality of Grendel's mother;

- the importance of «Beowulf» for the literature;

- stylistic devices which were used in «Beowulf»; heroic epic.

- the importance of poem about Beowulf as the sample of ancient

Also it would be interesting to suggest students to read aloud the abstract from "Beowulf», to translate it in Ukrainian and to compose sentences which are able to prove that the some words can be used as a Verb and as a Noun.

Guard.Air. Care. Cup. Trust.Field. Fire. Meet. Miss. Fill. Return. Rush . Sleep.

Another interesting way of mastering knowledge on folklore is the watching of small videos which are devoted to the Celtic mythology. During the videoconferencing it is possible to discuss the gods and goddesses, mythological creatures, legends and fairy tales. Students have the opportunity to describe the depicted landscapes, nature; to describe the appearance of various characters; to compare mythological motives. After this the students are given QrCodes or the additional links and at home they have to fill in the blank places.

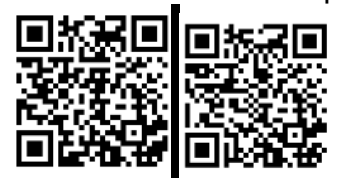

\begin{tabular}{|l|l|l|l|l|l|}
\hline Name & Appearance & Ability & Name & Appearance & Ability \\
\hline Abhartach & & & Kelpie & & \\
\hline Changeling & & & Banshee & & \\
\hline Dullahan & & & Selkie & & \\
\hline
\end{tabular}


Серія: Педагогічні науки. - Вип.3. - Бердянськ : БДПУ, 2021. - 250 с.

\begin{tabular}{|l|l|l|l|l|l|}
\hline Spriggan & & & Aine & & \\
\hline Babd Catha & & & Bran & & \\
\hline Arawn & & & Brigid & & \\
\hline Morrigan & & & Dogda & & \\
\hline Lugh & & & Danu & & \\
\hline Cat Sidhe & & & Medb & & \\
\hline Leprechaun & & Y Ddraig Goch & & \\
\hline
\end{tabular}

The multimedia content can be varied from a still screenshot which was taken from a film to the whole movie or Cartoons, TV show, Weather forecasts, advertisement, announcement, slogan, Vlogs, TV program, documentary or educational film. You just have to be student-oriented and take into account their preferences during the realization of your pedagogical purpose. We suggest you to organize the discussions, surveys which could be done with the help of Google tools.

For example, during the work with the theme «English Folklore within modern reality" you are able to ask your students to watch at home some videos, films, based on English folklore. Suggest them to create and to discuss presentations which would be able to reveal and to underline the motives of English folklore which could be found in modern prose of film industry.

Actually there are various forms which would be interesting for the realization within the distance learning. If you have the opportunity, you should organize the lesson-meeting. You'll have to invite some interesting guests to your conference. This could be the stake-holder, the professor from another department, student from the parallel group, the native speaker, the teacher from the secondary school, the writer or the poet. Ask your students to prepare ppt presentations, to create small informational videos on the given topic. Let students to conduct the lesson and present the certain topic for the «invited guest». In the end of the meeting ask the «invited guest» to express his opinion.

The business game involves the life situation or the problem which must be solved during the Zoom conference. Divide students in two groups and ask them to create the business-plans for the modern resorts on the seaside (using new vocabulary).

The lesson-concert allows to reveal the creative abilities and talents of your students-musicians because they are able to prepare some songs, poems of artistic works which could be implemented during the presentation of the educational material. You are able to visit this link:

https://www.youtube.com/watch?v=x-qUrU3etGo\&t=58s

An integrated lesson could be realized by two teachers of different fields of studies: English, Ukrainian, Literature, Physics, Art, etc. the task of such lesson is to find, analyze and present some ideas, definitions, notions which could be connected within the reality or within the imaginary world.

The Lesson-discussion helps us to reveal the students' ability to set, to ground and analyze the problem, to solve it during the determined time. Certainly they must be equipped by the additional information or 
algorithms. This will make them to to conduct the analysis, to formulate conclusions, to interpret result of the activity.

https://www.youtube.com/watch?v=IPHJ3xDDFy8

Translation practice reveals the students' abilities to create their own verses, poems or to translate the existing songs. For example during the Interactive course of English (the lesson was conducted with the help of ZOOM) we suggested students to choose the song or the verse and the teacher had to translate their favourite song. Next lesson was devoted to the watching musical video of this song, to the discussion of the content of the original verse and translation. Students and pupils of the school № 11 (who were invited with the help of the active link in ZOOM) were really motivated and got interested in developing their own poetic personality. These are samples of translation which were made by Oksana Khalabuzar.

\begin{tabular}{|c|c|}
\hline $\begin{array}{l}\text { Кузьма Скрябін } \\
\text { «Люди як кораблі» }\end{array}$ & $\begin{array}{l}\text { Переклад англійською - к.пед.Н., доц. } \\
\text { Халабузар О.А }\end{array}$ \\
\hline $\begin{array}{l}\text { Я не твій брат - ти не сестра моя } \\
\text { Ніколи не розказуй мені - } \\
\text { Хто і в чому є винний на нашій } \\
\text { землі - } \\
\text { Люди, як кораблі }\end{array}$ & $\begin{array}{l}\text { Nor l'm your bro, nor you're sister to me } \\
\text { And please, never-never-never tell me } \\
\text { Who's guilty in our land or during these trips } \\
\text { People are really like ships }\end{array}$ \\
\hline $\begin{array}{l}\text { Кожен пливе поки хвиля несе } \\
\text { I поки глибока вода } \\
\text { Глибока і темна до самого дна } \\
\text { До самого-самого дна }\end{array}$ & $\begin{array}{l}\text { Carried by wave, each ship's trying to sail, } \\
\text { And while there's deep water around. } \\
\text { It's so pervasive and dark till seabed } \\
\text { Till abyss-like scaring seabed. }\end{array}$ \\
\hline $\begin{array}{l}\text { На глибині зустрічаються всі } \\
\text { Так ніби в морі місця нема } \\
\text { І труться бортами, аж стогне } \\
\text { земля } \\
\text { Від зависті, підлості й зла }\end{array}$ & $\begin{array}{l}\text { And at this depth we all meet and congest } \\
\text { In the sea, as there is no space. } \\
\text { And we squeeze with our boards in this race. } \\
\text { While Earth's howling from evil, disgrace. }\end{array}$ \\
\hline $\begin{array}{l}\text { Хтось не доплив, бо йому } \\
\text { помогли } \\
\text { Набрати повні трюми води } \\
\text { Бо стати героями тої війни } \\
\text { Дуже хотіли вони. }\end{array}$ & $\begin{array}{l}\text { Someone has sunk due to somebody's help } \\
\text { To fill their holds or to overwhelm. } \\
\text { Cause they saw themselves in this poor realm } \\
\text { As the heroes of war in the helm. }\end{array}$ \\
\hline $\begin{array}{l}\text { А до берега тихо хвилі несуть } \\
\text { Поранені душі живих кораблів } \\
\text { А від берега знову в море ідуть } \\
\text { Ті хто вірив і правду знати хотів }\end{array}$ & $\begin{array}{l}\text { And the waves are just carrying easy so slight, } \\
\text { So wounded souls of some living ships. } \\
\text { And the coast farewells with the greatest } \\
\text { delight } \\
\text { New souls-ships who desire the truth in the } \\
\text { trips. }\end{array}$ \\
\hline $\begin{array}{l}\text { Наш Океан знає більше ніж ми } \\
\text { Секрети всі у нього на дні } \\
\text { А ми ходим зверху, великі й малі } \\
\text { Люди як кораблі }\end{array}$ & $\begin{array}{l}\text { Ocean just knows much more secrets than we, } \\
\text { And secrets are on the bottom. So deep. } \\
\text { And we sail above, big or small, trying to dip. } \\
\text { People are just like the ships. }\end{array}$ \\
\hline $\begin{array}{l}\text { Гордо пливем - і не вірить ніхто } \\
\text { Шо ним зацікавилось зло } \\
\text { І серед вітрів ми не чуєм щурів, } \\
\text { Які прогризають нам дно }\end{array}$ & $\begin{array}{l}\text { Proudly sail and just nobody thinks } \\
\text { That evil has already interested in. } \\
\text { Within the winds we don't spot that we sink } \\
\text { Due to rats, which are gnawing us in. }\end{array}$ \\
\hline А до берега тихо хвилі несуть & And the waves are just carrying easy so sligh \\
\hline
\end{tabular}


Поранені душі живих кораблів

А від берега в море ідуть

Ті хто вірив і правду знати хотів
So wounded souls of some living ships.

And the coast farewells with the greatest delight

New souls-ships who desire the truth in the trips.

\begin{tabular}{|l|l|}
\hline \multicolumn{1}{|c|}{$\begin{array}{c}\text { Ліна Костенко «За правду, браття, } \\
\text { єднаймось щиро» }\end{array}$} & \multicolumn{1}{|c|}{ Переклад англійською - к.пед.н., } \\
доц. Халабузар О.A
\end{tabular}

The conducted work proved that that the implementation of distance forms of teaching provides individualization of the process of professional development of the future teacher. However we should determine the required and perfect balance of online and offline studies which would be useful and adequate for the realization of all educational goals within the modern global society. Thus the prospect of our further scientific activity is the research of methods of formation of soft skills with the help of the nonstandard methods of distance and offline education.

\section{References}

Власенко Л., Никитенко О. Дистанційна освіта та ії функції у процесі навчання. URL : http://dspace.nuft.edu.ua/jspui/bitstream/123456789/12 170/1/6Vlas.pdf

Жевакіна Н. Педагогічні умови організації дистанційного навчання студентів гуманітарних спеціальностей у педагогічному університеті : автореф. дис. на здобуття наук. ступеня канд. пед. наук: 13.00.04. Луганськ, 2009. 20 с.

Краткая история развития дистанционного образования. URL : http://dtraining.web-3.ru/introduction/history/

Околесов О. Системный подход к построению электронного курса для дистанционного обучения. Педагогика. 1999. № 6. С. 50-56.

"Distance learning" Merriam-Webster.com Dictionary, Merriam-Webster. URL : https://www.merriam-webster.com/dictionary/distance\%20learning

Khalabuzar Oxana. Interactive Course of English. Poetic Meeting. URL: https://www.youtube.com/watch?v=x-qUrU3etGo\&t=58s

Khalabuzar Oxana. Interactive Learning Aspects of the Professional Training Soft Skills. URL : https://www.youtube.com/watch?v=IPHJ3xDDFy8

\section{References}

Vlasenko, L., Nykytenko, O. (2004). Dystantsiyna osvita ta yiyi funktsiyi u protsesi navchannya [Distance education and its functions in the learning process]. 
http://dspace.nuft.edu.ua//spui/bitstream/123456789/12170/1/6Vlas.pdf

[in

Ukrainian].

Zhevakina, N. (2009). Pedahohichni umovy orhanizatsiyi dystantsiynoho navchannya studentiv humanitarnykh spetsial'nostey $u$ pedahohichnomu universyteti [Pedagogical conditions for the organization of distance learning of students of humanities at the Pedagogical University] (Thesis abstract). Lugansk [in Ukrainian].

Kratkaya istoriya razvitiya distantsionnogo obrazovaniya [A Brief History of the Development of Distance Education]. URL: http://dtraining.web3.ru/introduction/history/ [in Russian].

Okolesov, O. (1999). Sistemnyy podkhod k postroyeniyu elektronnogo kursa dlya distantsionnogo obucheniya [A systematic approach to the construction of an electronic course for distance learning]. Pedagogika - Pedagogy, 6, 50-56. [in Russian].

"Distance learning" Merriam-Webster.com Dictionary, Merriam-Webster. URL : https://www.merriam-webster.com/dictionary/distance\%20learning [in English].

Khalabuzar, O. (2021). Interactive Course of English. Poetic Meeting. URL: https://www.youtube.com/watch?v=x-qUrU3etGo\&t=58s [in English].

Khalabuzar, O. (2021). Interactive Learning Aspects of the Professional Training Soft Skills. URL : https://www.youtube.com/watch?v=IPHJ3xDDFy8 [in English].

\section{АНОТАЦІЯ}

Стаття присвячена актуальним питанням застосування мультимедійного контенту в умовах дистанційного навчання. Авторами зазначено, що в сучасних умовах глобальних пандемічних процесів, які спричинили карантин на різних рівнях освітньої системи, дистанційне навчання стало одним із найбільш доцільних способів навчання, завдяки його здатності не загрожувати учасникам освітнього процесу. Ураховуючи фракт популярності впровадження різноманітного мультимедійного контенту серед здобувачів загальної середньої освіти, метою статті є визначення значущості його як способу інтенсифрікації дистанційного навчання. Українські вчені підкреслюють, що роль педагога трансформувалась і розширювалася, тому що він має бути координатором та організатором освітнього процесу. Ця трансформація змушує вчителя творчо працювати, координувати освітній процес, удосконалювати навчальні курси, підвищувати якість змісту освіти, співпрацювати з учнем, активізувати його пізнавальну діяльність.

Освітній мультимедійний контент може включати різні матеріали, які представлені на різних освітніх платформах та інших онлайн-ресурсах, наприклад Skype, ooVoo, iChat, Google Meet i FaceTime або Flash Meeting та ін. Деякі з цих ресурсів вільні від реклами, і це має впливати на вибір. Під час дистанційного навчання автори вважають за краще працювати на платформі Zoom, яку заснував Ерік Юань у квітні 2011 року. 3 того часу Zоот завоював величезну популярність завдяки своїм яскравим можливостям. Це можна пояснити тим, що Zоот можна використовувати з різними системами (Android, MacO, Windows, Linux moщо). Також, як переваги, відзначаємо те, що він безкоштовний протягом 40 хвилин відеоконферениії, яка може об'єднати до 100 учасників. Крім того, учасники мають можливість поділитися інформацією за допомогою демонстрації своїх екранів; спілкуватися в чаті, щоб показати свою реакцію. У рамках вивчення іноземних мов та зарубіжної літератури відеоконференцзв'язок довів свою ефрективність та продуктивність. Таким чином, під час планування уроку можемо запропонувати поділитися навчальним матеріалом, додати мультимедійний контент, який буде стимулювати позитивну мотивацію учасників. Наприклад, працюючи 3 матеріалом, автори пропонують надіслати кілька Qrcodes $з$ додатковою інфрормацією та попросити учнів переглянути матеріал, скласти кілька завдань $i$ підготувати свої звіти для обговорення. Авторами надано зразки практичних 
Серія: Педагогічні науки. - Вип.3. - Бердянськ : БДПУ, 2021. - 250 с.

завдань, що залучають мультимедійний контент, сприяючи інтенсифрікації освітнього процесу в умовах дистанційного навчання. Проте ми маємо визначити необхідний і ідеальний баланс онлайн та офлайн навчань, який був би корисним та достатнім для реалізації всіх освітніх цілей у сучасному глобальному суспільстві, що ми визначаємо перспективою нашої подальшої наукової діяльності.

Ключові слова: мультимедійний контент, дистанційне навчання, освітні цілі. 